\title{
Pengawasan Dinas Lingkungan Hidup Terkait Dengan Pencemaran Lingkungan oleh Limbah Industri di Kota Cilegon
}

\section{Thoriq Aziz ${ }^{1}$}

Universitas Sultan Ageng Tirtayasa, Indonesia thoriqaziz78@gmail.com

\section{Khoirul Huda ${ }^{2}$}

Universitas Sultan Ageng Tirtayasa, Indonesia hudakhoirul1999@gmail.com

\author{
E-ISSN (2721-0646) \\ Recieved: \\ June 102020 \\ Revised: \\ December 112020 \\ Accepted: \\ December 142020 \\ Doi Number \\ https://doi.org/10.37950/ijd.v2i3.58
}

\begin{abstract}
This research aims to find out the way or role of the Cilegon city environmental service in environmental control caused by industrial waste. To study this theme, this study uses two theories, environmental monitoring and pollution. Cilegon is one of the cities that has a high level of pollution. This happens a lot in the city of Cilegon especially in areas close to industrial areas such as Samangraya, Citangkil District, Kampung Cilodan Gunung Sugih, Ciwandan District, South Ring Road Crossing (JLS). The effect of industrial waste has an impact on the health of residents around the industrial area directly affected by the waste. From data obtained by the Cilegon City Health Office in 2018, there were 21,745 people with non-pneumonic cough and 661 pneumonia sufferers. This makes the city government of Cilegon must increase its supervision of environmental pollution caused by the Cilegon city industry.
\end{abstract}

Keywords: environmental politics, supervision, environmental pollution

\begin{abstract}
Abstrak
Penelitian kali ini bertujuan untuk mengetahui cara atau peran dari dinas lingkungan hidup kota cilegon dalam pengawasan lingkungan yang di sebabkan oleh limbah industry. Untuk mengkaji tema ini, penelitian kali ini menggunakan dua teori yaitu pengawasan dan pencemaran lingkungan. Cilegon menjadi salah satu kota yang mempunyai tingkat pencemaran yang cukup tinggi. Hal ini banyak terjadi di Kota Cilegon terutama di daerah yang dekat dengan wilayah industry seperti Samangraya,
\end{abstract}


Volume 2 Issue 3, December 2020

http://hk-publishing.id/ijd-demos

Kecamatan Citangkil, Kampung Cilodan Gunung Sugih, Kecamatan Ciwandan, Persimpangan Jalan Lingkar Selatan (JLS). Pengaruh limbah industri ini berdampak terhadap kesehatan warga sekitar daerah industri yang secara langsung terkena limbah tersebut. Dari data yang diperoleh dinas kesehatan Kota Cilegon tahun 2018 lalu, tercatat ada sekitar 21.745 pengidap batuk non pneumoni dan 661 penderita pneumoni. Hal ini membuat pemkot cilegon harus meningkatkan pengawasan terhadap pencemaran lingkungan yang di sebabkan industry kota cilegon.

Kata Kunci: politik lingkungan, pengawasan, pencemaran lingkungan

\section{Pendahuluan}

Pembangunan merupakan salah satu kegiatan yang sedang dilakukan oleh pemerintah Indonesia menuju ke arah negara yang lebih baik dan lebih modern dalam rangka menjamin keberlangsungan hidup masyarakat nya dan juga peningkatan kualitas hidup masyarakat.Pembangunan yang digencarkan terlihat sangat pesat sekali dari pembangunan yang terus dilakukan tiap tahun nya dan secara keberlanjutan. Pembangunan keberlanjutan merupakan suatu proses yang dilakukan untuk memenuhi kebutuhan masyarakat sekarang tanpa mengorbankan pemenuhan generasi masa depan.

Indonesia sedang mengalami kemajuan yang sangat pesat di sektor industri baik industri skala kecil maupun skala besar seperti industri minyak dan gas, industri baja, industri kimia, dll.Kemajuan yang pesat ini memberikan dampak yang cukup positif terhadap perekonomian nasional dan juga terhadap penurunan tingkat pengangguran setiap daerah yang terdampak dengan kemajuan tersebut.Kemajuan ini tidak cukup mengagetkan bila melihat revolusi industri yang semakin berdampak ke setiap negara yang mana ini sudah diwanti-wanti oleh presiden Jokowi tentang revolusi industri 4.0.disamping dengan massif nya perkembangan industri nasional yang terus bergerak maju, hal ini tidak dibarengi dengan didera nya masalah lingkungan yang diakibatkan oleh limbah-limbah industri yang semakin banyak.

Pencemaran merupakan masuknya zat atau energy bahkan komponen lain ke udara atau ke air yang mengakibatkan berubahnya struktur yang ada dalam air maupun udara, Itulah garis besar arti dari pencemaran.Masih banyak nya pembuangan limbah hasil produksi tanpa dilakukan pengolahan terlebih dahulu. Pada dasarnya dikarenakan jika setiap industri harus mengolah terlebih dahulu limbah hasil produksi mereka itu akan berdampak pada keuangan perusahaan yang mana perusahaan tidak ingin mengeluarkan uang yang lebih banyak hanya untuk mengolah limbah hasil produksi mereka. Limbah industri sendiri yang ada di Cilegon bisa dibilang dalam tahap yang cukup berbahaya mengingat banyak nya industri kimia, industri baja, dan industri lain yang menghasilkan limbah yang sangat mencemari lingkungan sekitar. Dalam hal ini DLH bersama pemerintah kota Cilegon belum ada keseriusan dalam menanggulangi pemcemaran limbah industri yang sudah berulang kali terjadi. Yang terbaru limbah PT. Dover Chemical yang memakan 7 anak sekolah dan harus dilarikan kerumah sakit akibat dari ledakan gas Plant B PT. Dover. Perlunya penanganan dan tindak tegas terhadap pelaku pencemaran lingkungan tidak dibarengi dengan tindakan yang dilakukan oleh pemerintah kota Cilegon terkait dengan permasalahan lingkungan tersebut. Selain kurang nya tindakan yang dilakukan pemerintah kota Cilegon kurang nya personil dilapangan, tidak adanya laboratorium lingkungan di kota Cilegon, dan 
belum adanya SOP dalam melakukan pengawasan membuat permasalahan lingkungan sulit teratasi di kota Cilegon.

Pengawasan yang dilakukan oleh DLH pun dinilai kurang maksimal dengan hanya ada 5 personil di lapangan yang melakukan pengawasan di lapangan yang seharusnya bisa $\mathrm{h}$ teratasi dengan mudah. Pengawasan yang dilakukan oleh dinas lingkungan hidup terhadap perusahaan yang menghasilkan limbah industri tidak dilakukan secara berkala. Tentu ini salah satu cabang permasalahan yang seharusnya mudah diatasi karena dinas lingkungan hidup mempunyai wewenang terhadap industri yang menghasilkan limbah yang dapat mencemari lingkungan. Yang seharusnya, menurut peraturan Daerah Kota Cilegon Nomor 2 tahun 2004 tentang Pengendalian Pencemaran dan kerusakan lingkungan yang tertulis bahwa pengawasan dilakukan periode 6 bulan 1 kali. Hal ini berawal dari personel lapangan yang kurang memadai yang harus mengawasi puluhan bahkan ratusan industri yang menghasilkan limbah tiap tahun nya. Dalam hal ini, peneliti menanyakan keseriusan dinas lingkungan hidup dan pemerintah kota Cilegon dalam mengawasi industri yang menghasilkan limbah yang mencemari lingkungan dan juga bagaimana dinas lingkungan hidup ini bekerja didalam setumpuk masalah yang harus diselesaikan?

Sanksi yang diberikan untuk para pelaku industri yang mencemari lingkungan juga dinilai tidak terlalu memberatkan.Hal itu terlihat dari sering nya beberapa perusahaan terlibat dalam pencemaran lingkungan seperti PT. Dover yang sudah sering sekali terlibat dalam hal itu sehingga masyarakat sekitar merasa perlu adanya pemindahan kampung mereka agar tidak terkena dampak dari pencemaran lingkungan yang dilakukan oleh PT. Dover Chemical. Hal ini kembali lagi, dikarenakan kurang nya personel dalam lapangan yang bekerja menangani setiap kasus ataupun mengawasi kegiatan industrial yang berada di kota Cilegon yang berjumlah lebih dari puluhan.

\section{Kerangka Teori \\ Pengawasan}

Pengawasan memiliki satu arti kata yaitu awas yang artinya dapat melihat dengan baik, dan di awali dengan kata peng dan berakhiran an dengan adanya imbuhan kata tersebut juga merubah arti dari pengawasan ialah penilikan atau penjagaan. Jadi dapat di simpulkan bahwa pengawasan merupakan penjagaan suatu kegiatan sehingga tidak menyimpang terhadap aturan-aturan yang sudah di buat.

Sedangkan Pengawasan menurut Jerry H Makawimbang (2012 :7) yaitu suatu kegiatan yang sistematis sesuai standar dalam perencanaan dan juga membandingkan kegiatan yang sudah berjalan dengan standar yang telah di tentukan sebelumnya. Menetapkan dan mengukur segala penyimpangan yang terjadi sehingga semu sumber daya organisasi dapat di pergunakan dengan cara yang efektif dan efisien.

Pengawasan yang efektif haruslah memenuh syarat sebagai berikut menurut Handoko (2005; 373), yaitu:

1. Akurat.

Artinya setiap informasi dalam kegiatan harusalh akurat sesuai aturan yang ada, karna jika informasi dalam kegiatan tidak akurat maka akan menimbulkan masalah yang seharusnya tidak ada.

2. Tepat waktu. 
Dimana sebuah informasi atau data harus di sampaikan secara tepat waktu, agar setiap evaluasi atau perbaikan bias di laksanakan secara cepat sehingga apa yang di capai sesuai dengan tujuan.

3. Objektifif dan menyeluruh.

Segala informasi yang di sampaikan harus bersifat objektif dan juga menyeluruh, sehingga informasi yang di sampaikan bias lebih jelas.

4. Terpusat pada titik-titik pengawasan strategis.

Setiap pengawas harus focus dengan apa yang di awasi sehingga tidak terjadi tumpeng tindih dalam pengawasan yang akan mengakibatkan kesalahan yang fatal.

5. Realistik secara ekonomis.

Penggunaan biaya dalam setiap kegiatan haruslah transparansi agar dana yang sudah di rencanakan cukup dan sesuai dengan rencana.

6. Realistik secara organisasional.

Setiap pengawasan harus harmonis dan berhubungan baik antar organisasi atau anggota.

7. Fleksibel.

Artinya pengawasan harus fleksibel terhadap ancaman atau tanggapan dari luar sehingga tidak memicu suatu konflik. yaitu:

Handoko(2003;361) juga mengklasifikasikan tipe pengawasan menjadi tiga tipe,

1. Pengawasan pendahuluan (feedforward control).

Handoko menjelaskan pengawasan pendahulu merupakan cara untuk mengantisipasi masalah atau penyimpangan yang terjadi di setiap kegiatan, dan pengawasan pendahuluan ini untuk mengkoreksi rencana setiap kegiatan sebelum di laksanakan

2. Pengawasan yang dilakukan bersama dengan pelaksanaan kegiatan (concurrent control).

Pengawasan ini di lakukan pada saat kegiatan berlangsung dan prosedurprosedur harus di setujui agar kegiatan tersebut bisa di lanjutkan .

3. Pengawasan umpan balik (feedback control).

Pengawasan ini merupakan pengawasan untuk mengukur hasil dari suatu kegiatan yang sudah di laksanakan atau sudah terjadi sehingga bias mengetahui apa saja kekurangan atau masalah yang terjadi, sehingga dalam pengawasan yang akan datang bias lebih baik lagi.

\section{Pencemaran Lingkungan Hidup}

Pencemaran lingkungan yang "masuk atau dimasukkannya makhluk hidup, zat, energi, dan/atau komponen lain ke dalam lingkungan hidup oleh kegiatan manusia sehingga melampaui baku mutu lingkungan hidup yang telah ditetapkan". Sesuai dengan pengertian dalam Pasal 1 nomor 14 Undang-Undang 32 Tahun 2009. Selain itu pencemaran bisa dilihat dari perubahan yang terjadi baik perubahan secara fisik, kimia atau biologis yang di sebabkan oleh suatu aktifitas ataupun benda yang ada di sekitar yang akan mengganggu kesehatan, ataupun mengganggu aktifitas manusia. (Imam Supardi, 2003:25).

Menurut Stephanus Munadjat Danusaputro merumuskan pencemaran lingkungan sebagai berikut: 
"pencemaran adalah suatu keadaan,dalam mana suatu zat dan atau energi diintroduksikan ke dalam suatu ligkungan oleh kegiatan manusia atau oleh proses alam sendiri dalam konsentrasi sedemikian rupa, hingga menyebabkan terjadinya perubahan dalam keadaan termaksud yang mengakibatkan lingkungan itu tidak berfungsi seperti semula dalam arti kesehatan, kesejahteraan, dan keselamatan hayati" (Muhamad Erwin, 2008:36).

\section{Metode Penelitian}

Metode penelitian yang akan digunakan pada penelitian kali ini adalah metode penelitian deskriptif kualitatif. Istilah penelitian kualitatif sendiri menurut Kirk \& Miller (1988:23) berawal dari pengamatan kualitatif yang ditentang oleh pengamatan kuantitatif. Kemudian mereka berdua mendefinisikan bahwa metodologi kualitatif merupakan sebuah tradisi pada pengetahuan sosial yang mefokuskan pada pengamatan terhadap manusia dalam kekuasaannya sendiri dan juga berhubungan dengan orang orang dalam bahasannya dan juga peristilahannya (Nasution, 2003). Menurut Sukmadinata (2005) dasar penelitian kualitatif adalah "konstruktivisme yang berasumsi bahwa kenyataan itu berdimensi jamak, interaktif dan suatu pertukaran pengalaman sosial yang diinterpretasikan oleh setiap individu". Menurut Starauss dan Corbin (1998:24), yang dimaksud penelitian kualitatif adalah "jenis penelitian yang dicapai atau diperoleh melalui prosedur prosedur statistik atau cara cara lain dari kuantitatif".

Penelitian ini dilaksanakan pada Dinas Lingkungan Hidup Kota Cilegon dan PT. Dover Chemical yang terletak di kota Cilegon. Adapun informan penelitian dalam penelitian ini adalah sebagai berikut:

- Kepala Bidang penataan dan penataan perlindungan pengelolaan lingkungan hidup Dinas Lingkungan Hidup Kota Cilegon.

- Kepala Seksi Pembinaan, Pengawasan dan Penegakan Hukum Dinas Lingkungan Hidup Kota Cilegon.

- Masyarakat sekitar PT. Dover Chemical

Dalam penelitian ini Metode pengumpulan data yang kami gunakan adalah dengan cara studi literatur dengan mengambil sumber dari berbagai buku, jurnal maupun skripsi yang berkaitan dengan tema yang kami ambil. Dengan kata lain peneliti menganalisis dan menyimpulkan isi dari jurnal, buku, website oficial yang sesuai dengan tema yang kami ambil.

Data Primer adalah data pokok yang diperoleh setelah melakukan penelitian dari beberapa responden yang berkaitan dengan masalah dan tujuan penelitian permasalahan yang diteliti, yaitu meliputi pengawasan yang dilakukan oleh Dinas Dinas Lingkungan Hidup Kota Cilegon dan PT. Dover Chemical, faktor-faktor yang mempengaruhi proses pengawasan PT. Dover Chemical serta mengenai indikator menentukan standar pengawasan, tindakan penilaian, melakukan tindakan perbaikan sanksi terhadap pelanggaran yang melanggar SOP yang telah ditetapkan.

Data Sekunder adalah data yang digunakan sebagai sarana pendukung untuk memahami masalah yang akan diteliti yang diperoleh oleh kantor Dinas Lingkungan Hidup Kota Cilegon dan PT. Dover Chemical sebagai berikut: 


\section{Hasil dan Diskusi}

Kota Cilegon adalah salah satu kota yang dikenal sebagai kota baja karena karena di kota ini banyak sekali industri baja lahir dan tumbuh salah satu nya PT. Krakatau Steel (KS). Kota Cilegon tidak hanya di kenal sebagai kota baja melainkan sebagai salah satu kota yang ditunjuk sebagai tempat proyek-proyek strategis nasional. Dalam lingkunp geografisnya Kota Cilegon sangat dekat dengan pantai dan bukan wilayah agraris yang mana sangat menguntungkan bagi para investor guna menyalurkan investasi di kota tersebut. Tentu dengan banyak nya proyek strategis nasional yang dibangun di Kota Cilegon akan memangkas tingkat pengangguran yang sampai saat ketika jurnal ini ditulis mencapai angka $9.68 \%$ yang terus meningkat dibandingkan tahun lalu sebesar $9.33 \%$. peningkatan petumbuhan ekonomi yang terus digenjot dan juga investasi yang semakin banyak membuat beberapa aspek penting harus dikorbankan salah satunya lingkungan. Yang banyak orang tidak ketahui bahwasannya dengan banyaknya industri yang ada Kota Cilegon membuat Cilegon menjadi salah satu kota yang mempunyai tingkat pencemaran yang cukup tinggi. Hal ini banyak terjadi di Kota Cilegon terutama di daerah yang dekat dengan wilayah industry seperti Samangraya, Kecamatan Citangkil, Kampung Cilodan Gunung Sugih, Kecamatan Ciwandan, Persimpangan Jalan Lingkar Selatan (JLS).

Pengaruh limbah industri ini berdampak terhadap kesehatan warga sekitar daerah industri yang secara langsung terkena limbah tersebut. Dari data yang diperoleh dinas kesehatan Kota Cilegon tahun 2018 lalu, tercatat ada sekitar 21.745 pengidap batuk non pneumoni dan 661 penderita pneumoni. Pneumoni merupakan infeksi yang menimbulkan peradangan paru-paru pada kantong udara disalah satu atau dua paru-paru yang dapat berisi cairan.Sebagian besar penderita ispa berada di wilayah industri yaitu Ciwandan, Pulomerak, jombang. Dalam kasus PT. Dover Chemical yang baru-baru ini terjadi akibat dari kebocoran gas Pan B yang mengakibatkan beberapa warga harus dibawa kerumah sakit karena tidak kuat menahan bau gas yang terus menerus dikeluarkan.Bahkan beberapa warga meminta untuk direlokasi dari tempat tersebut karena sudah berkali-kali terjadi kebocoran gas yang dialami PT. Dover Chemical.Hal ini yang menjadi dasar mengapa di Cilegon sendiri memiliki pencemaran lingkungan yang cukup tinggi.Dalam menangani kasuskasus seperti ini perlu adanya SOP yang jelas terkait pengendalian pencemaran lingkungan yang dilakukan oleh PT. Dover Chemical. Dalam beberapa kasus kebelakang seperti kasus yang dialami PT. Indorama, Dinas Lingkungan Hidup mendapati dokumen lingkungan hidup yang dimiliki oleh PT. Indorama belum diperbarui. Hal ini diketahui setelah terjadi nya kasus meledak nya serbuk kimia Purified Terephtihalic Acid (PTA) yang menyebabkan jalan menjadi licin dan mengakibatkan gatal. Setiap elemen baik dari warga, pemerintah maupun LSM harus melakukan pengawasan terkait pencemaran lingkungan yang dilakukan perusahaan yang tidak bertanggung jawab.

\section{Pelaku kontrol pengawasan pencemaran lingkungan}

Dalam hal ini pelaku kontrol pengawasan merupakan subjek yang sangat penting dalam pengawasan pencemaran lingkungan.Tanpa adanya pelaku tersebut maka pencemaran lingkungan tidak dapat dicegah dengan baik. Dalam pelaku kontrol ada 2 bagian yang bisa melakukan kontrol yaitu internal dari bagian pengawasan lingkungan dinas lingkungan hidup dan eksternal bisa dilakukan siapa saja baik dari DPRD, masyarakat, atau LSM yang memberikan laporan kepada dinas lingkungan hidup yang 
kemudian menindak lanjuti kejadian tersebut. Sejauh ini, pihak dari internal pun tidak begitu efektif dalam melakukan pengawasan pencemaran lingkungan. Terbukti, dengan adanya 2 kejadian sebelumnya seperti PT Indorama dan PT. Dover Chemical internal pengawasan pencemaran lingkungan dinas lingkungan hidup akan menyelesaikan sebuah kasus jikalau hanya ada laporan saja. Ketidaksigapan dari dinas lingkungan hidup yang berimbas terhadap pencemaran lingkungan yang kemudian menjadi penyakit kepada masyarakat sekitar yang terdampak. Dalam melakukan pengawasan pencemaran lingkungan hidup dibutuhkan personil yang memadai yang harus memantau kurang lebih 200 perusahaan yang menghasilkan limbah industri. Dalam hal ini dinas lingkungan hidup tidak memiliki personil yang cukup dalam melakukan pengawasan hal ini diungkap oleh kepala bagian pengawasan dinas lingkungan hidup yang mengatakan bahwa hanya ada beberapa personil yang melakukan pengawasan yang tentu saja sangat sulit dalam melakukan pengawasan apalagi untuk melakukan pengawasan dalam kurun waktu 6 bulan sekali.

\section{Anggaran dalam melakukan pengawasan pencemaran lingkungan hidup}

Dalam melakukan pengawasan pencemaran lingkungan hidup perlu adanya anggaran yang mencukupi dalam kegiatan tersebut.Anggaran tersebut bisa bersumber dari APBN, APBD. Dalam tahun anggaran 2019 anggaran yang dikeluarkan APBD dalam melakukan pengawasan pencemaran lingkungan hidup sekitar Rp.700 juta yang mana dalam hal pengawasan sendiri hal ini sangat kurang memadai mengingat peralatan yang digunakan dalam melakukan pengawasan pencemaran lingkungan sangat besar sekali seperti alat untuk mengukur kualitas udara yang harganya mencapai 5 miliar. Apalagi dalam pengawasan nya Dinas lingkungan hidup tidak memiliki laboratorium pengawasan pencemaran lingkungan hidup dan hanya mengandalkan pihak ketiga. Dinas lingkungan hidup tidak memiliki SOP dalam melakukan pengawasan pencemaran lingkungan hidup

Dalam pengawasan yang dilakukan dinas lingkungan hidup SOP merupakan salah satu bagian yang terpenting dalam melakukan kegiatan tersebut. Karena dengan SOP hal-hal yang perlu diperhatikan akan diketahui dengan mudah. SOP dalam melakukan pengawasan pencemaran lingkungan yang dilakukan dinas lingkungan hidup hanya berdasarkan prinsip yang tertuang dalam SK rencana kerja bidang pengawasan pengendalian dan perusakan lingkungan dinas Lingkungan hidup. Dalam SK tersebut disebutkan bahwa yang pertama tentang investasi data kegiatan tahun sebelumnya, yang kedua tentang pembahasan data penyusunan rencana operasional, yang ketiga tentang rencana operasional pengedaran surat monitoring kepada perusahaan yang mengeluarkan limbah, yang keempat pembuatan format tugas, berita acara, laporan periodic ( pertiga bulan dan perenam bulan) dan yang kelima pelaksanaan.

\section{Kegiatan pengawasan pencemaran lingkungan}

Dalam hal kegiatan ini jadwal yang dilakukan dalam melakukan pengawasan pencemaran lingkungan yang dilakukan oleh dinas lingkungan hidup bagian pengawasan dapat dilakukan setiap bulan, triwulan ataupun 6 bulan sekali. Jika pengawasan dilakukan oleh pihak yang berada diluar dinas lingkungan hidup seperti masyarakat atau LSM bisa dilakukan setiap saat dan juga bukan merupakan tanggung jawab dari dinas lingkungan hidup. Dalam pelaksanaan nya dalam melakukan pengawasan pencemaran lingkungan hidup hanya dilakukan setiap 1 tahun sekali 
dikarenakan personil yang kurang memadai dan juga anggaran yang diperlukan sangat tidak mencukupi.

\section{Conclusion}

kota cilegon merupakan kota industri hal ini yang membuat kota cilegon menjadi salah satu kotta yang mempunyai tingkat pencemaran yang tinggi, hal ini banyak terjadi di terutama di wilayah yang dekat dengan industri. pencemaran lingkungan di kota cilegon sangat berdampak langsung bagi kesehatan masyarakatnya, seperti dari data dinas kesehatan tahun 2018 yang mencatat sekitar 21 juta jiwa mengalami masalah pada paru paru mereka.

Hal ini yang arus menjadi perhatian penting bagi pemkot cilegon untuk meningkatkan pengawasan terhadap industri-industri di kota cilegon agar bisa mengurngi pencemaran lingkungan. salah satu cara untuk meningkatkan pengawasan lingkungan perlu adanya pelaku kontrol pengawasan pencemaran lingkungan, pelaku kontrol pengawasan lingkungan merupakan subjek yang sangat penting dalam pengawasan pencemaran lingkungan, tanpa adanya pelaku kontrol pengawasan maka pencemaran lingkungan tidap dapat di cegah dengan baik, selain perlu adanya pelaku kontrol pengawasan tentunya perlu adanya anggaran yang cukup untuk pengawansan lingkungan di kota cilegon, pemerintah kota cilegon sebenanya sudah mengelontorkan dana APBD untuk melakukan pengawasan lingkungan sejumlah 700 juta, namun hal ini masih di rasa kurang, mengingat peralatan yang di butuhkan dalam pengawasan lingkungan hidup yang sangat mahal. seperti salah satu contohnya alat untuk mengukur kualitas udara yang harganya mencapai 5 milyar rupiah.

Selain itu juga permasalahan yang menjadi penyebab pencemaran lingkungan yang tinggi di kota cilegon karena dinas lingkungan hidup tidak memiliki SOP dalam melakukan pengawasan pencemaran lingkungan, SOP merupakan salah satu bagian yang terpenting dalam melakukan suatu kegiatan, dengan adanya SOP pasti akan mudah dalam mengontrol pengawasan lingkungan di kota cilegon.

\section{Tentang Penulis}

Thoriq Aziz merupakan seorang mahasiswa semerster 6 di Universitas Sultan Ageng Tirtayasa asal Kota Cilegon, dia memang sangatlah tertarik dengan industri atau hal hal yang berkaitan dengan isu isu tentang lingkungan.

Khoirul Huda merupakan seorang mahasiswa semester 6 juga di Universitas Sultan Ageng Tirtayasa, ia merupakan mahasiswa yang berdomisili Bojonegara. Sama hal nya dengan penulis pertama, ia juga merupakan mahasiswa yang cukup tertarik dengan lingkungan.

\section{Ucapan Terimakasih}

Dengan selesai nya jurnal yang kami tulis ini, kami mengucapkan terima kasih yang sebesar besarnya kepada Tuhan yang Maha Esa karena telah memberi kami kesehatan sehingga kami mampu menyelesaian jurnal ini. Kami juga sangatlah berterima kasih kepada dosen mata kuliah Politik Lingkungan yaitu bung Dian Hikmawan karena telah membimbing kami sejauh ini hingga jurnla ini selesai. Kami juga berterima kasih kepada orang tua kami karena telah memberikan semangat serta doa kepada kami sehingga hami mampu untuk menyelesaikan jurnal ini. Terima kasih juga kami ucapkan kepada teman teman yang telah membantu dalam mengerjakan jurnal ini. 


\section{References}

Herlambang, Arie, Pencemaran Air Dan Strategi Penanggulangannya. Jurnal Peneliti Pusat Teknologi Lingkungan, Bppt Vol. 2, No. 12006

https:/ / www.cnnindonesia.com/nasional/20190708173421-20-410233/dki-ajukananggaran-beli-alat-ukur-udara-seharga-rp5-miliar

https:/ / bantenhits.com/2018/01/03/warga-cilegon-tuntut-tanggung-jawab-ptindorama-petrochemical/

https:/ / faktabanten.co.id/blog/2019/08/24/penderita-penyakit-pernapasan-dicilegon-meningkat-kawasan-industri-tertinggi/

https:/ / banten.bpk.go.id/?page_id=717

https:/ / www.kabar-banten.com/terdampak-polusi-pt-dover-chemical-berkali-kaliwarga-kalibaru-minta-direlokasi/

Mukarromi, Al. 2017. Pengawasan Badan Lingkungan Hidup Terhadap Limbah Industri Sagu Di Kabupaten Kepulauan Meranti (Studi Kasus Desa Sungai Tohor Kecamatan Tebing Tinggi Timur). Universitas Riau Fisip Vol.4 No. 1

Nasution, S. 2003. Metode Penelitian Naturalistik Kualitatif. Bandung : Tarsito

Sulaiman, Muhammad. 2019. Pengawasan Pencemaran Lingkungan (Studi Kasus Limbah Industri Kelapa Sawit Di Kabupaten Indragiri Hulu). Universitas Riau Fisip Vol. 6: Edisi I

Zendrato, E. 2010. Pengukuran Kadar Gas Pencemar Nitrogen Dioksida (No2) Di Udara Sekitar Kawasan Industri Medan. Medan: Universitas Sumatera Utara

Rusda, Isy Syabilla. Pengawasan Pemerintah Daerah Terhadap Pencemaran Limbah Industri Batik Di Kota Pekalongan Pada Tahun 2010-2014. Jurnal Universitas Diponegoro

Sugiyono. 2014. Metode Penelitian Kuantitatif, Kualitatif, Dan R\&D. Bandung: Alfabeta 